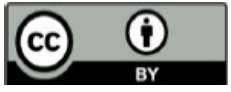

\title{
Teacher Competence in Reducing the Level of Aggression in the Classroom
}

\author{
Anna Kožuh ${ }^{1 *}$ \\ 'University of Primorska, Slovenia; AFM Krakow, Poland, e-mail: anna.kozuh@pef.upr.si
}

\begin{abstract}
The authoress of the text raises the issue of teaching problematic students. This phenomenon mainly concerns the inappropriate behaviour of students in lessons of various subjects as well as inappropriate reactions of teachers. The authoress attempts to analyze the main problem, searching for the causes and consequences of this problem in education. In the following parts of the text, she shows and tries to resolve the development of the problem, trying to convince the reader of the practical and theoretical importance of discussing problematic situations in the process of education. The consequences of problematic student behaviour, preparing future teachers for coping with problem students, teaching activities aimed at weakening the actions of a "problematic" student, the importance of competence in interpersonal communication in activities correcting the attitudes of troublesome students are one by one discussed in the text. The selected contents are supplemented with references to the cited literature and with the opinions of the authoress. The article is closed by conclusions together with an indication of directions and areas of further research and practice.
\end{abstract}

Keywords: teacher competence, problematic student behaviour, interpersonal communication.

\section{Introduction}

Overcoming a variety of challenges and teaching problems caused by problematic behaviour of students has gained notable significance in recent years. Coping with the behaviour of students that violate order and discipline in the classroom has been part of everyday life in the work of teachers for decades. However, recent studies indicate a discernible increase in this problem. Many surveyed teachers describe coping with situations caused by problematic students as the most serious teaching challenge (Dambach 2003; Kołodziejczyk, 2007; Libiszowska-Żółtkowska and Ostrowska, 2019; Olweus, 2007; Pyżalski, 2012; Urban, 2012). Initially, research in this area of teaching was limited mainly to the Scandinavian region (Åsemar, 1985; Olweus, 1980). Though in the 1980-s the importance of this problem was noticed in other parts of Europe and the world (Allen, Leadbeater and Aber, 1994; Grube and Morgan, 1990; Jessor, 1991; Jessor, Donovan and Costa, 1991; Newcomb and McGee, 1991; Necombet al., 2002; Skiba et al., 2006). The situation was discussed in numerous studies conducted in selected countries of the European Union as well as outside Europe, in such countries as Canada, Australia, Japan and the United States (Bronfenbrenner, 1979; Jessor and Jessor, 1977; White and Labouvie, 1994). The problem is described as difficult everywhere (Andrzejewska, 2014; Awang-Hashim, Kaur and Noman, 2015; Bakker and Costac, 2014; Pyżalski 2012). In the United States, as many as one-third of the surveyed teachers say that inappropriate student behaviour significantly interferes with their teaching process (Giroux, 2003; Hirschi, 1969; James and Freeze, 2006; Osgood et al., 1988).

Therefore, in her article, based on a literature review, the authoress attempts to show, two areas of competence that significantly limit or even eliminate problematic situations in teaching. One of these areas is the didactic workshop, as well as a teacher's competence in the area of good organization of work in classes with students. In this area, the teacher pays attention primarily to the knowledge and proper selection of various teaching methods and a well-prepared work plan with the students. While indicating the possibilities of working with searching methods, the author appreciates the importance of skillfully combining these methods with methods of knowledge assimilation. Search methods are irreplaceable in working with every student. They release his or her activity, interest in the problem and give the students the feeling that they come to school to discover certain knowledge themselves. These are certainly sufficient advantages of the search methods to be used as often as possible when working with problematic students. On the other hand, however, the importance of knowledge assimilation methods should be carefully considered, as they give the students a sense of security as a result of at least a very general understanding of the subject. Apart from that, these methods help the students search for cause"Corresponding author: anna.kozuh@pef.upr.si 
and-effect relationships in the content that is barely known.

The second pillar of the considerations of the authoress is the competence of teachers in interpersonal communication and their importance in working with problematic students. The authoress emphasizes the importance of the coherence of verbal and non-verbal communication in the teaching process. Such consistency expressed as the authenticity of a teacher significantly increases the effectiveness of teaching interactions. In the section about the importance of communication skills in working with problematic teaching, the ability to send and receive verbal messages was analysed (Dąbrowska-Bak and Pawełek, 2014; Kmiecić-Baran, 1995; Konieczna, 2019; Rejzner, 2004).

Another element of the reflection of the authoress is the ability of the students to actively listen to the teacher, which can, in effect, trigger more effective student activity, well-being, as well as develop their self-acceptance, which is essential for problematic students. In the final part of her article, the authoress discusses the strategy of avoiding ambiguity of messages and the strategy of making use of alternative methods of instruction for a student. The two strategies are of great importance in eliminating undesirable behaviour of students referred to as problematic.

\section{Consequences of students' problematic behaviour}

The problematic student is a threat not only to himself, not only to the course of the teaching process, but is also a threat to the teacher, and more precisely to the teacher actions, reactions and motivation to work. The concepts of occupational burnout and professional stress of teachers, among the most important factors, emphasize the improper and sometimes even aggressive behaviour of students. Besides, which is very clearly stressed by the respondents in the research, studies preparing for the teaching profession do not provide sufficient knowledge on how to cope with situations of problematic students (Hamby, Finkelhor and Turner, 2012; Ostaszewski, 2014). Educational reality is even more difficult because the range of inappropriate student behavior is very extensive and extremely diverse.

The inappropriate actions of the students take the form of various types of aggression. Sometimes it is silence and failure to respond to teacher messages, sometimes it is damage to school property or teacher property, physical violence over weaker students in the classroom, vulgar messages directed at both classmates and teachers and other school staff, recording videos ridiculing students or teachers and posting them on websites, extorting money, blackmail and many other inappropriate behaviours (Mishna and Alaggia, 2005; Pyżalski, 2012). What behavioural violations of discipline are can be intuitively determined by almost anyone. The most common definition among teachers is that "these are behaviours that do not comply with generally accepted standards" (Kožuh 2017). A definition formulated in this way can be charged with many weaknesses. However, it is difficult to classify behaviours described in teaching as "difficult". Much depends on the situational context of the student behaviour and the mental structure of individual students themselves. Much depends on the situational context of the student's behaviour and the mental structure of individual students themselves some of the violent activities of the students are premeditated, whereas others are due to the lack of culture and reduced intellectual ability of a given student (Strykowska-Nowakowska, 2017; Zielińska, 2012). When trying to define such student's behaviour, referred to as difficult, several important conditions must certainly be taken into account such as serious disturbance or even making the work impossible for the teacher, violation of the right of other students to learn in class, posing a physical threat to other participants of the teaching process (Shechtman and Leichtentritt, 2004) or activity aimed at destroying someone property (Lewicka-Zelent, 2012; Wosik-Kawali, 2011). Violation of discipline should also be considered as an important criterion in the search for a classification of difficult situations (MacKenzie, 2019). This violation has many types of behaviour, of which at least two main types of behaviour, mentioned by Shechtman and Leichtentritt, 2004 , should be identified. The first type of such behaviour is a violation of discipline through negative behaviour. This category includes all situations preventing the teacher from conducting lessons in a manner consistent with the plan. It is a disturbance caused by a student during the lesson or student aggression directed against the teacher or other students. The second type of behaviour is a behaviour not focused on teaching tasks targeted at students. This second type of problem behaviour occurs most often when a student requested by the teacher does not take any actions or tasks during the lessons.

\section{Preparation of future teacher for coping with problematic students}

There are many important reasons why teachers should receive extensive knowledge about how to react in similar situations during their teacher-training studies (Guerin and Hennessy, 2004). One of the 
main goals of such training and education while studying is the fact that the high level of students' discipline in the classroom allows the teacher to spend more time on teaching the students new knowledge and skills, rather than focusing on proper student behaviour and discipline in class. Good preparation of the beginning teacher to solve difficult situations with a problematic student also creates better conditions for successful learning, i.e. learning with the use of teaching methods that promote durability of the acquired knowledge (Nęcki, Malszewski and Czerwiński, 2012). Permanence of knowledge is primarily guaranteed by search methods. When working with these methods, students should follow all the teacher's instructions, otherwise this part of teaching may prove to be too dangerous - for example, during an experiment or out-of-school trip. Working with a class or a group that is well-disciplined is also a good way to ensure the overall safety of students at school, which has now become an important element in assessing the school by parents and education authorities (Deptuła, 2013). Chaos in the classroom may also prevent the full implementation of the teaching method chosen by the teacher, so that this method often loses its meaning, being carried out only in part. Furthermore, if the students behave correctly, the teacher has more time and energy to be active during the lesson and is more motivated to work with students. Such a teacher is eager to reach for more innovative and creative teaching solutions (Łukasik, AdamskaStaroń and Piasecka, 2009). In the situation of optimal student behaviour, the teacher also has much more time to present new contents in the classroom, instead of silencing students and solving behavioral problems. Moreover, proper responses of the teacher can also teach students attitudes that foster their own development Appropriate teacher reaction in probem situations also develops empathy of students and indicates the needs and rights of other people in the team (MacKenzie, 2019).

The aspect of teachers' health and well-being is also consequential. Difficulties in dealing with students' inappropriate behaviour are often associated with bearing high emotional costs for teachers (Awang-Hashim, Kaur and Noman, 2015; Muchacka-Cymerman, 2017). The feeling of helplessness and negative emotions result in serious psychic burden (Bakker and Costac, 2014). Therefore, one should remember that reducing the number of frustrating situations resulting from the difficulty of maintaining discipline, may result in teachers feeling more satisfied with their work, and thus contribute to the improvement of the relationship between the teacher and students. A teacher who has difficulty in coping with inappropriate student behaviour, including different kinds of student aggression, feels increasingly exhausted. In such a mental condition, their motivation and effectiveness in dealing with difficult educational and didactic situations drop sharply. Apart from that, a teacher working in intense emotional arousal may begin to manifest authoritarian tendencies and react alternately with aggression or withdrawa (Zielińska, 2012). Unfortunately, such behavior can have disastrous consequences. It may be the cause of further and more serious misconduct of students according to the rule that the cause produces the effect, which in turn produces the cause (Strykowska-Nowakowska, 2017; Wosik-Kawali, 2011). Such a situation deepens the already very complicated position of the teacher. Eventually, it can even result in extremely problematic situations in the classroom (Kiezik-Kordzińska, 2008). These include, for example, events in which a teacher who is unable to exceed the boundaries of ethical behaviour by, using violence against students; or vice versa, in which students use violence against a teacher. An example of the latter may be one of events in a Polish school registered by students and then posted on the website. A short video shows a high school teacher who is ridiculed and attacked by students, and eventually students put a bin full of trash on his head during the lesson (https://www.youtube.com/watch?v=Dgle4OfL-zo).

\section{Teaching activities aimed at weakening the actions of the "problematic" student}

In the literature on the subject, we can find many dissertations, analyses and concepts exploring the problem of a problematic student in the teaching process. Detailed review of the literature also lets one to get acquainted with a wide variety of ideas aimed at reducing and optimizing difficult situations in the teaching process resulting from the activities of problematic students. There are also critical voices regarding the very notion of discipline at school. On the basis of empiric experience Kohn (2006) indicates that none of the teachers who participated in the study, and in whose classes, there was order, did not intentionally introduce solutions aimed at maintaining discipline. The researcher emphasizes that order in the classroom is the result of many other teacher activities. According to Kohn, the pivotal factors in the area of proper student behaviour and maintaining discipline during lessons are the teaching skills. They determine the structure of the teaching, its division into logical and closely related stages. Such a systematic and logic division makes it easier easier for students to understand new content, arouses their curiosity and at the same time develops their motivation. Such a formula of classes connected with well-developed skills in teacher interpersonal communication also activates students at many moments 
of the lesson. Most important, however, are the teaching competencies regarding the use of various teaching strategied and methods. Undoubtedly, the most important among them are search methods and classes in which this type of methods becomes dominant. Most often, these are lessons in which students themselves discover some knowledge by acting as researchers. However, this does not mean that the assimilation method should be undervalued or neglected. They are, of course, valuable, because students cannot come to new knowledge only as a result of experience, experiments and of the method of trial and error. In every collision with a problem it is the student's knowledge that is extremely important, as he or she can quickly apply it in response to a given issue. It is important to remember that students come to school to acquire new knowledge. However, it is more interesting for them to stay at school when they can discover this knowledge by themselves, at least in part. Hence the knowledge of methods that teachers are looking for, including problem methods, or role-playing methods, is so momentous in making suggestions of lessons interesting for their students (Łukasik, Adamska-Staroń and Piasecka, 2009). Depending on the structure of a class and the extent of the tasks that students have, the selection of searching methods can be an extremely weighty element of the teaching process that helps solve problems with troublesome students (Mąrry-Kupiec, 2015). Criticism of the teaching efforts to maintain discipline, derived from Kohn's research, is is a valuable contribution to edcational literature. He emphasizes that most of the activities activities focussing on strictness do not achieve the intended results (Kohn, 2006).

As a result, students often toe the line and show off their obedience only to get better grades or appraisal in the eyes of their teacher and school authorities. However, applying such disciplinary teacher strategies does not usually result in the most-anticipated changes in students. They are mainly two-sided manipulations on the side of the teachers and the students, and they do not lead to regular changes in an ethical and moral nature. As a result of such approach, students rarely acquire the right attitudes and social skills that teachers and contemporary school exoect from them. Therefore, it is worthwhile deepening research in the area of teacher activities that discipline students. It is also worth analyzing their effectiveness or lack of expected results when working with a problematic student. At the same time, this means that additional knowledge and specific skills of teachers, proposed both during their teachertraining studies, as well as in the form of training and improving ocupationally active teachers, may prove to be crucial in the process of solving various situations with problematic students. Therefore, research should also extend in the direction of the possibility of introducing new contents during teacher-training studies and the professional work of a teacher. Syllabuses of teacher-training studies often lack a subject that would offer such competence in a practical form. On the other hand, during the training sessions for professionally active teachers the most common problems are the problems with working with the IT devices or the right software at school, not always taking into account the difficulties in working with other people (Pyżalski, 2012).

\section{The importance of interpersonal communication in actions correcting attitudes of problematic students}

The diversity of student misconduct is so great that it is difficult to develop even very general strategies for effective teacher behaviour. However, it is possible to undertake an analysis of the teacher activities that are focused on solving the problem and may be helpful in situations of inappropriate behaviour of a problematic student. Among the teaching strategies, apart from the attractively conducted classes, which I emphasized and discussed earlier, a good result can be achieved by the competence of interpersonal communication mentioned in this article. I want to develop this problem here.

In this part of the article I would like to consider the problem of correct interpersonal communication of the teacher, which is one of the key competences of a teacher in the process of education. Along with skills related to the proper organization of work, the crucial aspect for the teacher is to conduct the teaching process constructively. An extensive discourse on this issue could be observed in the past decades. Various aspects of interpersonal communication are subject to detailed research (Nęcki, Maliszewski and Czerwiński, 2012; Ostaszewski, 2014; Strykowska-Nowakowska, 2017; Wosik-Kawali 2011).

The theoretical and practical significance of analysing interpersonal communication skills in education is of great value. As a starting point for her considerations on the importance of interpersonal communication in the education process, the authoress adopted Watzlawick's Pragmatics of Human Communication formulated in the mid-twentieth century. In one of his axioms Watzlawick assumes that it is impossible not to communicate with others (Watzlawick, 1974). I fully agree with this axiom. This means that silence, which can express fatigue, boredom, disapproval, resentment, hostility or some other emotions, is also a message. In an educational situation, it may be the silent teacher, ignoring the student, 
not asking questions or not responding to provocative messages of the students. It may also be an unresponsive student who is silent, to any contact attempts made by the teacher. Moreover, Watzlawick assumes that every behavior is a form of communication in itself. The educational space is filled with both verbal and non-verbal messages. At the same time, the importance of consistency between these two types of communication in the process of teaching should be heartily emphasized. This coherence, expressed as authenticity of the teacher, significantly increases effectiveness of didactic activities of teachers in education.

Students usually first detect non-verbal messages in their teacher, because at the beginning of the educational process they mainly listen and observe (Libiszowska-Żółtkowska and Ostrowska, 2019). The next step for students is to focus on receiving verbal messages and to seek coherence for both types of teacher communication. Awareness of these stages can strongly affect planned activities of the teacher in this sphere (Danilewska, 2005). At the same time, such consciousness, resulting in specific changes in the activities applied by a teacher can facilitate and accelerate subsequent stages of establishing correct cooperation between the students and their teacher.

\section{The most significant elements of interpersonal communication for the successful management of the educational process}

The authoress of the article wishes to identify and analyze fragments of interpersonal communication, which are the most significant in the educational process in her opinion. Many factors have an impact on the efficient and effective use of the interpersonal communication competence in teaching. The first of these factors is sending and receiving verbal messages in a skillful way. The language of the teacher and the way his thoughts are formulated are as important as the way in which verbal messages are received by students with various verbal problems. In addition to the ability to high-quality literary verbalization the teacher must also have general cultural competence and knowledge about the laws governing the behaviour of people in certain situations. According to Mądry-Kupiec, 2015, the level of communication competences of teachers, with few exceptions, is not particularly high. The authoress believes that virtually none of the fields of teacher studies develops these skills in a separate way, and the basics of rhetoric and eristics, so principal for the work of a teacher, were withdrawn from the faculties of teacher studies a long time ago. Teachers often remain helpless in the face of difficulties in explaining complex and complicated content in a clear and transparent way. Increasingly, they also experience failure in conducting discussions and the art of bringing disputes to a favourable solution. Lack of competence in this area has also been highlighted by the authors of other dissertations (Andrzejewska, 2014; Bakker and Costac, 2014; Kołodziejczyk, 2004). Mądry-Kupiec also rightly proves, that teachers are not always able to decode student messages transmitted through different channels in the right way. The ability to observe and react quickly to the most current events in the classroom becomes extremely important here. It also happens that teachers sometimes do not control their own verbal and non-verbal communication channels well enough (Król-Fijewska, 2013).

Another difficulty in the didactic process is creating certain discoveries and findings in the course of discussion-based learning methods. Thus, shaping the apropriate process of interpersonal contacts together with the ethics and culture of these contacts seems to be an important educational challenge. In the process of communicating with the student during the lesson special attention should be given to reactions and any teacher messages sent to students who have poorly developed verbal skills or speech defects. For a teacher, the skill of patiently waiting for the student to finish his speech becomes extremely important here. Only in such a situation can the teacher receive a complete picture of the student's knowledge (Deptuła, 2013). In addition to the above-discussed verbal communication, an equally important challenge in teaching is also the ability to send and receive non-verbal messages. In this group of factors, the tone and articulation of teacher's voice seems to be extremely important. It is crucial that the voice is not monotonous, sleepy, too loud, too quiet, screaming, nervous or fading. Nonverbal communication in the form of voice modulation plays a vital and not always properly recognised role in teaching. The most important elements of knowledge during the lesson can be emphasized and accentuated by the tone of voice. Besides, the class can also be successfully disciplined by the tone of the voice, in particular by silencing the voice. A teacher well equipped with interpersonal communication skills can also correctly use non-verbal communication elements other than the tone of voice. These include, among others, eye contact, formal distance from the student, moderate and sensitive gestures and proper body posture (Kiezik-Kordzińska, 2008).

It should be stressed that according to Watzlawick, there are two basic levels of communication, 
i.e. the level of contents constituting verbal messages, and the relational levels, which include, tone of voice, facial expression, gestures, distance, eye contact and others, are made up by the element of the third recipient. The element is the belief that every participant in the communication process creates his or her version of what is observed and experienced. This interpretation causes that credibility and trust in the information provided by the teacher or, for example, respect for the teacher, can have very different consequences in the teaching process. It depends on both the teacher and the student with whom the teacher communicates. According to the Watzlawick theory, each participant in the communication process believes that the behaviour of the other person is caused by his own behaviour. Watzlawick theory shows that interpersonal communication is complex and cyclic. It is a process in which each party uniquely contributes to changing the way information is relayed. This element of Watzlawick theory is of particular importance for all activities in the field of education. This element of interpersonal communication and the awareness of its existence in the activities of professionally active teachers should be the subject of more detailed research and analyses.

Another element of the interpersonal communication process having a strong impact on the effects of the education process, is the ability to listen actively. Active listening to the teacher triggers the student activity, the well-being, raises the student self-acceptance and gives the student a sense of respect for his/her dignity. In turn, active listening allows the teacher to avoid some passivity in the reception of the student. It means that active listening skills enable both sides of the educational process to be ready for the proper presentation of one's own point of view, argumentation and defence of one's own opinion. In this process, the teacher should improve his skills in the field of constructive criticism and asking questions that will activate the student (Andrzejewska, 2014). The student in the course of active listening to the teacher is, in turn, implemented in the process of developing readiness to listen to others, and, what is very important, taking into account the views of other students and other people in the group. It should be firmly stressed to teach a student proper interpersonal communication effectively, the teacher must have this competence and continually improve and develop it. There are also other elements of interpersonal communication that are principal for the teacher's effectiveness in teaching. These are two strategies: the strategy for avoiding message ambiguity and the strategy for using alternative commands for the student.

\section{Strategies for avoiding message ambiguity and using alternative commands for the students}

Apart from the elements mentioned above, the ability to use two communication strategies in education can also play a vital role in the didactic work with a problem student. The first one is the strategy to avoid message ambiguity. This strategy is seldom mentioned in preparation for the profession, which is why less experienced teachers often use ambiguous messages (Strykowska-Nowakowska, 2017). These messages are usually incomprehensible to students or, worse, improperly understood. Hence, they give students, especially problematic ones, the possibility of behaving in a way that are not present in the teacher's message or instruction. These are usually messages that contain information on how to behave, but not the right ones that inform the students what they should do. Such messages as "don't walk all over the classroom" or "don't talk in class" have just such a wrong and incorrect perspective. In the case of the message "don't walk around the class" the students learn that they are not allowed to walk. At the same time, however, they may think that they are allowed to do other things, such as dancing, running, talking, screaming, standing in front of other colleagues' benches or doing many other activities that are not walking in the classroom. The message "don't talk in class" also sounds ambiguous. Apparently, this message means that the students should not talk to their classmates. However, this message is very much in conflict with the student's responsibility to communicate, speak and discuss in class with both the teacher and other students in the classroom. The ambiguity of these messages is that to carry out the command students may behave in different ways. All these behaviors will be the execution of the teacher's order, that is, for example, to stop walking or remain silent. It does not mean, however, that if the students adapt to this message it will result in steps to master the classroom and situations expected by the teacher (Konieczna, 2019).

Another suggested solution for interpersonal communication in the area of teaching interaction is to formulate instructions for the student in the form of an alternative. Less experienced teachers sometimes suggest solutions in the form of mandatory messages. These are messages stating that the student cannot make a choice (Kiezik-Kordzińska, 2008). However, you should be aware that for a student such a situation is extremely uncomfortable, especially when it happens in front of the whole class. Submission to the teacher can sometimes be perceived by the student, especially a problem student, as a moment 
of losing prestige in the eyes of his or her peers.

An order that does not contain an alternative message only indicates how the student should behave at the moment, according to the teacher. An order containing an alternative, for example, "put the phone in a backpack or put it on my desk" gives the student at least two options to choose. Even better, when there are more choices for a student. By choosing one of them, he still carries out the teacher's instructions, but with the knowledge that he did what he decided to do.

\section{Conclusions}

The discussed solutions applied in the field of work with problematic students refer to several dimensions and in particular to the applied training methods, the skills of organizing work with the students and competence in the field interpersonal communication. In the light of the reviewed literature on the subject, these diversified and large-scale domains constitute an almost perfect mosaic of effective didactic methods applied by teachers in their work with problematic students. On the other hand, it should be plainly emphasized that the undertaken analysis focuses only on narrow areas of the extremely profuse spectrum of this complex issue. There are two main threads in the analysis carried out in this article. On the one hand, the didactic workshop of a teacher plus his or her ability to apply various teaching methods and create a coherent plan of work with their students, and on the other hand, to use teacher skills in interpersonal communication, which together make up an attempt to find successful solutions in their work with problematic students. These two strands of search are connected by an axiological dimension, mainly related to the reliable diagnosis of the student capabilities and the correct attitude of the teacher towards the student. According to the authoress of the article, the most important element is the teacher's diagnosis and reflection regarding mainly what actions are to be taken coping with the student referred to as the "problem student" will prove the most effective as well as when and how to take them. The great difficulty and challenge are finding individual didactic solutions that will positively change the student behaviour and at the same time help maintain good relations with the student and have a positive impact on his or her development.

Analysis of the problem has allowed the identification of several basic elements conducive to achieving effects in the educational process and improving the relationship between teachers and students. This exploration has also proved the necessity of undertaking further detailed research on didactic work with problem students. In the opinion of the authoress of the article, one of the research directions should be the teachers' skills in establishing contact with problematic students. Specific studies should include teachers active in the profession, examining how they acquire skills in the two areas indicated. The aspect of updating their didactic knowledge, which offers changes and new solutions significantly more often than the area of substantive content related to a specific subject of teaching is very important.

In the future, research should also cover teachers starting work in the profession, determining the level of their competence in the field of working with search methods and communication competences, including, in particular, careful listening to the student, the art of paraphrasing, as well as proper diagnosing and evaluation of the students. Further research in this area may bring valuable results indicating new and effective solutions for didactic work with problematic students. The authoress of the article maintains that detailed research should also provide the answer to the question: whether one should seek to introduce a separate subject in the course of preparation for the teaching profession, which will concern communication strategies in the process of education, or should this content be a part of various subjects implemented during teacher training studies, highlighting the latest trends and modifications in this area. The problem analyzed in the article is developmental. It is not only the number of students who have learning problems that are growing. The scale and variety of behaviour in class, defined as problematic behaviour, is also increasing. In turn, it raises the urgent need to find effective solutions for both, teachers starting work in the profession and for those who have experienced various types of behaviour of problematic students for years. The attempt made by the authoress to analyze difficult areas of work with a problem student indicates the directions of further research and their importance for the effectiveness and practice of the process of education shortly.

\section{Conflict of interests}

The author declare no conflict of interest. 
Kožuh, A. (2020). Teacher competence in reducing the level of aggression in the classroom, International Journal of Cognitive Research in Science, Engineering and Education (IJCRSEE), 8(3), 145-153.

\section{References}

Allen, J. P., Leadbeater, B. J., \& Lawrence Aber, J. (1994). The development of problem behavior syndromes in at-risk adolescents. Development and Psychopathology, 6, 323-323. http://www.people.virginia.edu/ psykliff/pubs/publications/dl2.pdf

Andrzejewska, A. (2014). Dzieci i młodzież w sieci zagrożeń realnych i wirtualnych: aspekty teoretyczne i empiryczne [Children and youth in the network of real and virtual threats: theoretical and empirical aspects]. Warszawa: Wydawnictwo Difin.

Åsemar, C. (1985). Studie-och yrkesorienteringens framväxt i grund-och gymnasieskola: en beskrivning av mål, organisation och metoder (rev). [Study and training orientations from the ground floor and ground and gym school: in description of the organization, organization and methods (rev)]. Umeå universitet. https://www.diva-portal.org/smash/get/ diva2:152452/FULLTEXT01.pdf

Awang-Hashim, R., Kaur, A., \& Noman, M. (2015). The interplay of socio-psychological factors on school engagement among early adolescents. Journal of Adolescence, 45, 214-224. https://doi.org/10.1016/j.adolescence.2015.10.001

Bakker, A. B., \& Costa, P. L. (2014). Chronic job burnout and daily functioning: A theoretical analysis. Burnout Research, 1(3), 112-119. https://doi.org/10.1016/j.burn.2014.04.003

Bronfenbrenner, U. (1979). The ecology of human development. MA: Harvard University Press.

Dambach, K. E. (2003). Mobbing w szkole: jak zapobiegać przemocy grupowej [Mobbing at school: how to prevent group violence]. Gdańsk: Gdańskie Wydawnictwo Psychologiczne.

Danilewska J. (2005). Powstrzymać agresję u progu szkoły [Stop aggression on the threshold of school], Kraków. Wydawnictwo Uniwersytetu Jagiellońskiego.

Dąbrowska-Bąk M., Pawełek K. (2014). Opresja w szkole [Oppression at school]. Warszawa. Wydawnictwo ŻAK -Wydawnictwo Akademickie.

Deptuła, M. (2013). Odrzucenie rówieśnicze: Profilaktyka i terapia [Peer rejection: Prevention and therapy]. Warszawa: Wydawnictwo Naukowe PWN.

Giroux, H. (2003). Racial injustice and disposable youth in the age of zero tolerance. International Journal of Qualitative Studies in Education, 16(4), 553-565. https://doi.org/10.1080/0951839032000099543

Grube, J. W., \& Morgan, M. (1990). The structure of problem behaviours among Irish adolescents. British Journal of Addiction, 85(5), 667-675. https://doi.org/10.1111/j.1360-0443.1990.tb03529.x

Guerin, S., \& Hennessy, E. (2004). Przemoc i prześladowanie w szkole: skuteczne przeciwdziałanie agresji wśród młodzieży [Violence and Bullying at School: Effective Combating Aggression among Young People]. Gdańsk: Gdańskie Wydawn. Psychologiczne.

Hamby, S., Finkelhor, D., \& Turner, H. (2012). Teen dating violence: Co-occurrence with other victimizations in the National Survey of Children's Exposure to Violence (NatSCEV). Psychology of violence, 2(2), 111. https://doi.org/10.1037/ a0027191

Hirschi, T. (1969). Causes of delinquency. Berkeley, CA: University of California Press. http://garfield.library.upenn.edu/ classics1980/A1980KG03900001.pdf

James, S., \& Freeze, R. (2006). One step forward, two steps back: Immanent critique of the practice of zero tolerance in inclusive schools. International Journal of Inclusive Education, 10(6), 581-594. https://doi.org/10.1080/13603110500264636

Jessor R. (1991). Risk behavior in adolescence: A psychosocial framework for understanding and action, Journal of Adolescent Health, 12(8), 597-605. https://doi.org/10.1016/1054-139X(91)90007-K

Jessor, R. (1992). Risk behavior in adolescence: A psychosocial framework for understanding and action. Developmental review, 12(4), 374-390. https://doi.org/10.1016/0273-2297(92)90014-S

Jessor, R., \& Jessor, S. L. (1977). Problem behavior and psychosocial development: A longitudinal study of youth. New York: Academic Press.

Jessor, R., Donovan, J. E., \& Costa, F. M. (1991). Beyond adolescence: Problem behavior and young adult development. New York: Cambridge University Press.

Johnston, L. D., O'Malley, P., \& Bachman, J. (1988). The generality of deviance in late adolescence and early adulthood. American Sociological Review, 53, 81-93. https://doi.org/10.2307/2095734

Kiezik-Kordzińska, E. (2008). Sztuka unikania konfliktów: jak rozmawiać z nauczycielami i kolegami? [The art of avoiding conflicts: how to talk to teachers and colleagues?]. Warszawa. Wydawnictwa Szkolne i Pedagogiczne WSiP.

Kmiecik-Baran, K. (1995). Poczucie alienacji: destruktywne i konstruktywne sposoby minimalizacji [Sense of alienation: destructive and constructive ways to minimize]. Wydawnictwo Uniwersytetu Gdańskiego. Gdańsk: Wydawca: Gdańskie Wydawnictwo Psychologiczne GWP.

Kohn, A. (2006). Beyond discipline: From compliance to community. Alexandria, VA: Association for Supervision \& Curriculum Development. https://alfiekohn.org/teaching/pdf/Beyond\%20Discipline.pdf

Kołodziejczyk, J. (2004). Agresja i przemoc w szkole. Konstruowanie programu przeciwdziałania agresji i przemocy w szkole [Aggression and violence at school. Constructing a program to counteract aggression and violence at school], Kraków. Wydawnictwo Uniwersytetu Jagiellońskiego.. http://ww.powiatwolowski.pl/files/file/Agresja-przemoc-wszkole.pdf

Kołodziejczyk, J. (2007). Szkolny program przeciwdziałania agresji i przemocy [School program for counteracting aggression and violence]. Psychologia w Szkole, 1(13), 109-116.

Konieczna A. (2019). Nasza klasa. Społeczne zachowania przestrzenne i reguły dystansu w społeczności klas szkolnych [Our class. Social spatial behavior and rules of distance in the school class community]. Warszawa. Wydawnictwo Akademii pedagogiki Specjalnej.

Kožuh A. (2017). Kompetencje nauczyciela w pryzmacie dydaktyki [Teacher's competences in the prism of didactics]. Koper: Zalozba Univerze na Primorskem.

Król-Fijewska M. (2013). Stanowczo, łagodnie, bez lęku [Firmly, gently, without fear]. Warszawa: Wydawnictwo W.A.B.

Lewicka-Zelent, A. (2012). Obniżanie poziomu przemocy i lęku młodzieży gimnazjalnej [Lowering the level of violence and fear among junior high school students]. Lublin: Wydawnictwo Uniwersytetu Marii Curie-Skłodowskiej.

Libiszowska-Źółtkowska M., \& Ostrowska K. (2019). Agresja w szkolep [Aggression at school] . Warszawa. Wydawnictwo: Difin S.A. 
Kožuh, A. (2020). Teacher competence in reducing the level of aggression in the classroom, International Journal of Cognitive Research in Science, Engineering and Education (IJCRSEE), 8(3), 145-153.

Łukasik, B., Adamska-Staroń, M., \& Piasecka, M. (2009). Twórcze myślenie: kreatywny student i nauczyciel [Creative thinking: a creative student and teacher]. Częstochowa: Wydawnictwo AJD.

MacKenzie R. (2019). Kiedy pozwolić, kiedy zabronić w klasie [When to allow, when to forbid in class]. Gdańsk: Gdańskie Wydawnictwo Psychologiczne, GWP.

Mądry-Kupiec M (2015). Komunikacja werbalna nauczyciela na lekcji [Verbal communication of the teacher during the lesson]. Krakow: Wydawnictwo Naukowe Uniwersytetu Pedagogicznego.

Mishna, F., \& Alaggia, R. (2005). Weighing the Risks: A Child's Decision to Disclose Peer Victimization. Children \& Schools, 27(4), 217-226. https://doi.org/10.1093/cs/27.4.217

Muchacka - Cymerman, A., \& Tomaszek, K. (2017). Syndrom wypalenia w zawodzie nauczyciela i w roli ucznia. Przeglad literaturowy. Forum Oświatowe, 29(2(58), 95-115. https://forumoswiatowe.pl/index.php/czasopismo/article/view/526

Newcomb, M. D., \& McGee, L. (1991). Influence of sensation seeking on general deviance and specific problem behaviors from adolescence to young adulthood. Journal of personality and social psychology, 61(4), 614-628. https://doi. org/10.1037/0022-3514.61.4.614

Newcomb, M. D., Abbott, R. D., Catalano, R. F., Hawkins, J. D., Battin-Pearson, S., \& Hill, K. (2002). Mediational and deviance theories of late high school failure: Process roles of structural strains, academic competence, and general versus specific problem behavior. Journal of counseling psychology, 49(2), 172-186. https://doi.org/10.1037/0022-0167.49.2.172

Nęcki, Z., Maliszewski, W. J., \& Czerwiński, K. (2012). Komunikacja społeczna - negocjacje-edukacja. Perspektywa wielu kultur [Social communication - negotiations-education. The perspective of many cultures]. Toruń. Wydawnictwo: Adam Marszałek

Olweus D. (2007). Mobbing. Fala przemocy w szkole. Jak ja powstrzymać [Mobbing. A wave of violence at school. How to stop her]. Warszawa: Jacek Santorski \& Company Agencja Wydawnicza.

Olweus, D. (1980). Aggression in the schools: Bullies and whipping BOYS, Washington, Hemisphere Publ. European Journal of Social Psychology, 10(1), 101. https://doi.org/10.1002/ejsp.2420100124

Osgood, D. W., Johnston, L. D., O'Malley, P. M., \& Bachman, J. G. (1988). The generality of deviance in late adolescence and early adulthood. American Sociological Review, 53(1), 81-93. https://doi.org/10.2307/2095734

Ostaszewski, K. (2014). Zachowania ryzykowne młodzieży w perspektywie mechanizmów resilience [Risky behaviors of adolescents in the perspective of resilience mechanisms]. Warszawa: Instytut Psychiatrii i Neurologii.

Pyżalski, J. (2012). Agresja elektroniczna i cyberbullying jako nowe ryzykowne zachowania młodzieży [Electronic aggression and cyberbullying as new risky behaviors of young people]. Kraków: OWI. https://repozytorium.amu.edu.pl/ bitstream/10593/5939/1/Pyzalski_Cyberbullying_OK\%20-\%20Kopia1.pdf

Rejzner, A. (Ed.). (2004). Agresja w szkole: spojrzenie wieloaspektowe [Aggression in school: a multi-faceted view]. Warszawa: Wydawnictwo WSP TWP.

Shechtman*, Z., \& Leichtentritt, J. (2004). Affective teaching: a method to enhance classroom management. European Journal of Teacher Education, 27(3), 323-333. https://doi.org/10.1080/0261976042000290822

Skiba, R., Ritter, S., Simmons, A., Peterson, R., \& Miller, C. (2006). The Safe and Responsive Schools Project: A school reform model for implementing best practices in violence prevention. In S. R. Jimerson \& M. Furlong (Eds.), Handbook of school violence and school safety: From research to practice (p. 631-650). Lawrence Erlbaum Associates Publishers. https://psycnet.apa.org/record/2006-03632-041

Strykowska-Nowakowska, J. (2017). Kompetencje komunikacyjne nauczycieli. Studia Edukacyjne, (45), 311-328. https://doi. org/10.14746/se.2017.45.21

Urban B. (2012). Agresja młodzieży i odrzucenie rówieśnicze [Youth aggression and peer rejection]. Warszawa: Wydawnictwo: PWN Państwowe Wydawnictwo Naukowe.

Watzlawick (1974). An Anthology of Human Communication. California: Pala Alto, Science and Behavior Books.

White, H. R., \& Labouvie, E. W. (1994). Generality versus specificity of problem behavior: Psychological and functional differences. Journal of Drug Issues, 24(1), 55-74. https://doi.org/10.1177/002204269402400104

Wosik-Kawali D. (2011). Komuniakcja i edukacja - ku synergiczności porozumiewania się [Communication and education towards the synergy of communication]. Toruń. Wydawnictwo: Adam Marszałek.

Zielińska M. (2012). Jak reagować na agresję uczniów?: skuteczne techniki radzenia sobie z problemem [How to respond to student aggression?: Effective coping techniques]. Gdańsk: Wydawca: Gdańskie Wydawnictwo Psychologiczne GWP. 
Kožuh, A. (2020). Teacher competence in reducing the level of aggression in the classroom, International Journal of Cognitive Research in Science, Engineering and Education (IJCRSEE), 8(3), 145-153. 